International Journal of Linguistics, Literature and Culture
Available online at https://sloap.org/journals/index.php/ijllc/
Vol. 7, No. 6, November 2021, pages: 517-524
$\begin{aligned} & \text { ISSN: 2455-8028 } \\ & \text { https://doi.org/10.21744/ijllc.v7n6.1982 }\end{aligned}$

\title{
Development of Art, Culture, and Literature Attractions for Millennial Generations
}

\author{
Ikhwanuddin Nasution a \\ Asmyta Surbakti ${ }^{\text {b }}$ \\ Vanesia Amelia Sebayang ${ }^{c}$
}

\section{Article history:}

Submitted: 27 September 2021

Revised: 09 October 2021

Accepted: 18 November 2021

\section{Keywords:}

cultural tourism;

development art;

literature attractions;

millennial generation;

values;

\begin{abstract}
This article discusses the great potential of Tengku Amir Hamzah Stabat Park in Langkat Regency, Indonesia. The potential of the park can be used as the development of a new tourism phenomena by creating a cultural tourism market. The Langkat Malay community is known to have a high culture, but the influence of globalization causes cultural degradation. The development of cultural tourism is going to use because it is related to extracting traditional values. The trend of tourists today is a new experience through an unknown cultural heritage. The method used is descriptive-qualitative. Data were obtained from in-depth interviews, observations, FGDs, books, and other official sources. This article used cultural tourism, sustainable tourism, and creative economic development theories. The results showed that Tengku Amir Hamzah Stabat Park could be developed as an artistic, cultural, and literary attraction. The Millennial Generation of Langkat Regency still has an interest in the cultural heritage of Langkat Malays, therefore it needs to be preserved as the unique values of the region and used as tourist attractions at the local level. Tengku Amir Hamzah's work should be understood from a new perspective. The Industrial Revolution 4.0 is closely related to the development of cultural tourism.
\end{abstract}

International journal of linguistics, literature and culture (C) 2021. This is an open access article under the CC BY-NC-ND license (https://creativecommons.org/licenses/by-nc-nd/4.0/).

\section{Corresponding author:}

Ikhwanuddin Nasution,

Fakultas Ilmu Budaya, Universitas Sumatera Utara, Medan, North Sumatra.

Email address: ikhwanuddin25@gmail.com

\footnotetext{
${ }^{a}$ Fakultas Ilmu Budaya, Universitas Sumatera Utara, Medan, North Sumatra

${ }^{\mathrm{b}}$ Fakultas Ilmu Budaya, Universitas Sumatera Utara, Medan, North Sumatra

${ }^{\mathrm{c}}$ Fakultas Ilmu Budaya, Universitas Sumatera Utara, Medan, North Sumatra
} 


\section{Introduction}

Tengku Amir Hamzah Stabat Park has great potential in developing Langkat Malay arts and cultural attractions. The construction of this large park is intended to be a place of expression for writers and artists and cultural activists. The results of Surbakti et al. (2019), research shows that this park has not been used optimally. T. Zainuddin has started his activities in the park by involving students and the younger generation. In 2019, T. Zainuddin wrote a loud protest regarding the existence of a park that was empty of activities (Waspada March 31, page C1). The potential of the park is very supportive as a destination development and artistic, cultural, and literary attraction. Tengku Amir Hamzah's own works are widely known to foreign countries, especially Malaysia, which specifically includes his poems in the school curriculum (Richards, 2018; Bachleitner \& Zins, 1999).

The significant behaviour of domestic tourists has shifted to short-distance destinations after the COVID-19 pandemic, so Amir Hamzah Park, which is close to Medan City as the capital of North Sumatra Province, is a strategic place for tourists who use road trips. Nowadays, travel activities to get experience at a destination are one of the goals of people in travelling (Teguh, 2020). Diversification and development of destinations and attractions in Tengku Amir Hamzah Park can be used to capture the tourism market opportunities as well as to understand Tengku Amir Hamzah's works. The arts and culture of the Langkat Malay community are known to be different from other Malays (Takari, 2018).

The Langkat Malay community lives in a series of customs, is religious, and is familiar with ritual activities starting from the phase of birth to human death or the life cycle. The life cycle starts from customs related to human birth, customs during children, customs in marriage, customs of medicine, customs of traditional sports and performing arts, customs of eating or entertaining, the custom of the inauguration of traditional administrators, customs in communication, customs related to the day - Islamic religious holidays, to customs that regulate the procedures for human death and burial (Takari, 2018). The culture of the Langkat Malay community is still influenced by elements of animism, dynamism, and Hinduism even though they have embraced Islam. However, art, culture, and literary understanding in the form of poems by Tengku Amir Hamzah are starting to experience degradation because there are young people who are experiencing the impact of globalization (Surbakti et al, 2019).

Globalization is suspected as the cause because globalization is a historical trend that is very prominent in human life in the modern era which then results in homogenization (Sztompka, 2004). Globalization causes human dependence in all aspects such as politics, economy, and culture. However, the strong roots of culture and traditions inherent in the Langkat people do not make them uprooted and dissolved in a single culture according to the impact of globalization. Although in a shallow stage, the Langkat community is still familiar with the world of art until now and has the potential to be developed as a cultural tourism destination and attraction based on both material and nonmaterial cultural heritage.

According to Teguh (2020), the new tourism phenomenon so called New Tourism, mandates the important role of everything that is consumed by tourists. Intellectuals, values, longing for the past, and cultural heritage of ancestral heritage began to be sought as something new and interesting to learn. Destinations with relatively close distances are an option and of course with strict health protocols. The traditions of the Langkat community have the potential to be used as attractions in this new tourism phenomenon because they contain value-laden local wisdom. The development of traditional attractions towards intellectual needs can be understood according to the function of tradition as a hereditary policy, legitimacy of a view of life, a symbol of collective identity, and a place of escape from modern life.

A new perspective in understanding Tengku Amir Hamzah's Lyrical Poems and the musicalization of poetry makes the development of the park's potential a momentum related to the potential development of the tourism sector and creative economy that has been introduced by the Ministry of Tourism and Creative Economy of the Republic of Indonesia. As tourist destinations, Langkat Regency, the Azizi Grand Mosque area of Tanjung Pura, and Tengku Amir Hamzah Stabat Park are synonymous with the works and name of Tengku Amir Hamzah himself. New needs and the role of intellect in consuming attractions require a new interpretation in understanding Tengku Amir Hamzah's works which are very different from previous understandings. According to New Tourism's mandate, this trend is also a need for postmodern tourists (Wall et al., 2009; Boulanger \& Bréchet, 2005).

The results of Chitra (2019), show that Tengku Amir Hamzah is the most productive poet of the New Pujangga class of lyrical poetry in introducing archaic Malay words. Tengku Amir Hamzah is very adept at using harmonization of diction and rhyme in various themes and is written in quaternary stanzas resembling the rhyming patterns of traditional Malay pantun and resembles an interesting ballad style that can be developed in poetry musicals. The arts and culture of the Langkat Malay community as well as Tengku Amir Hamzah's literary works are 
the cultural capital of the Langkat Millennial Generation related to the Industrial Revolution 4.0., namely to build the nation through cultural tourism. Travel services, tourism and recreation services, and culture are part of the World Trade Organization (WTO) agreement with the Indonesian government (Kemenristekdikti, 2018). However, the science of cultural tourism is not yet known in North Sumatra (Surbakti et al., 2019).

\section{Materials and Methods}

This research used a qualitative descriptive model Bungin (2010), which examined the problems of consumer behaviour on products, namely tourist destinations and attractions based on art, culture, and literature at Taman Tengku Amir Hamzah Stabat with research units namely the community, art activists, and the ranks of the Department of Tourism and Culture of Langkat Regency. Primary data were obtained from in-depth interviews with observation-participation techniques and for focus group discussions, structured interview techniques were used. Secondary data were obtained from books, journals, sources from official archives, the internet, and other official documents. Referring to Cresswell (2015), data analysis was carried out by sketching ideas, taking notes, summarizing data, working with words, identifying codes, choosing themes, creating points of view, and displaying data related to tourism in Taman Tengku Amir Hamzah Stabat. The data analysis technique used triangulation in the form of combining various methods. The data analysis technique is analytical inductive (Kim et al., 2007; Shoval \& Raveh, 2004).

\section{Results and Discussions}

Sociocultural reality is a reality or situation that can be seen in real terms related to the conditions of human life in a group of people who are in a relationship with each other (Setiadi \& Kolip, 2011). The Langkat Malay community in general used to live as simple traditional farmers, fishermen, or work as laborers on industrial plantations. During the Dutch colonial era in Langkat, many large gardens were opened with export commodities such as palm oil, rubber, coffee, and tobacco with good quality. Environmental factors make the Langkat Malay community close to nature. They believe that not only humans have spirits (Koe et al., 2012; Gallicano, 2013).

Tepung Tawar is an important tradition in a series of ceremonies that have many symbolic meanings. Equipment in the implementation of plain flour must be considered carefully, such as sowing potions, rinjisan ingredients, and incense sticks whose ingredients are taken from certain types of plants that have meaning or value. The moral message of tepung tawar is a form of obedience to the ancestors. In fact, as ancestral heritage, tepung tawar used to be interpreted as a combination of cultural values and religious values that were sacred, sacred, and supernatural. In the past, plain flour was carried out solemnly accompanied by the blessings of the prophet and marhaban as a form of collective ideas belonging to the Langkat Malay community. However, as times change, tepung tawar is no longer interpreted as it used to be, although it is still being practised today (Takari, 2018).

The Langkat Malay community also experiences cultural degradation and tends to forget and be uprooted from their traditional roots. On the other hand, the younger generation of Langkat is also interested in the issues of preserving cultural heritage. There is a kind of longing for the past or in the process of searching for identity by studying traditions that have been carried out in the past as an expression of communicating with nature. This phenomenon is explained by Sztompka (2004), that society is always a process and is constantly changing at all levels of its internal complexity. At the macro level, there are economic, political and cultural changes. At the mezzo level, changes occur in groups, communities, and organizations. At the micro-level, there is a change in interaction and behaviour. The great potential of the cultural heritage of the Langkat Malay community needs to be studied and developed according to the tourism market segmentation (Lee \& Han, 2002; Squire, 1994).

The development of tourism potential is understood as an improvement effort or strategy implemented by the government, the private sector, and the community to increase destination resources through planning, developing, and monitoring the physical and non-physical elements of the destination. Potential development is also interpreted as the development of new products, which is carried out consciously by improving current products through product diversification, strategy studies, and programs to be implemented. Potential is everything contained in a place in which there is a unique and important cultural heritage that needs to be preserved and developed into tourist destinations and attractions. Each region has its own unique culture, traditions and customs according to the tastes

Nasution, I., Surbakti, A., \& Sebayang, V. A. (2021). Development of art, culture, and literature attractions for millennial generations. International Journal of Linguistics, Literature and Culture, 7(6), 517-524. https://doi.org/10.21744/ijllc.v7n6.1982 
and intellectual development of the people who support that culture (Spillane, 1994). The potential of Langkat's cultural heritage is very useful in efforts to develop the tourism industry. The vast Tengku Amir Hamzah Stabat Park with several buildings in it is very worthy and representative as a destination.

According to Teguh (2015), the embodiment of locality elements through strengthening the unique values of certain regions and local wisdom that is believed by the community to be used as tourist attractions must be encouraged as widely as possible in tourism development at the local level. This is very appropriate and needs to be implemented in Taman Tengku Amir Hamzah Stabat. The element of locality is very important in a tourism destination because:

a) Tourism resources are geographical, located in a place and outside attractions in the context of space and time.

b) Components or elements of tourism destinations that include attractions, the wider community, facilities and accessibility in the geographical area need to be preserved to remain in demand because they have ecological, economic and social allure and leverage.

c) The quality of the balance between ethical, aesthetic, and economic values is determined by the transformation of values and the intensity of interaction through a process of adaptation, co-optation, and adoption that goes well with minimal clashes and value bias or value hegemony or value dominance in tourism destinations. In planning, developing, and developing a destination, a proportional tourism destination governance model is needed.

According to Mariotti in Yoeti (2013), tourism potential is everything that is contained in a tourist destination as well as an attraction so that people want to visit that destination. Furthermore, Gunn \& Var (2020), explains that there are at least four aspects that make the potential to become a leading attraction for tourists, such as Taman Tengku Amir Hamzah. First, as an effort to maintain environmental sustainability, second, to improve the welfare of the people in the area, third, to ensure visitor satisfaction, and fourth to increase the integration and development of the community around the area and its development zone. Attraction is attached to a tourist destination as something that is consumed, enjoyed, or seen. In the concept of the new tourism phenomenon, there are different needs in terms of consumption for tourists. New experience or knowledge is educational and has important values about something important. According to the Law of the Republic of Indonesia Number 10 of 2009 it is explained that tourism or everything related to tourism is a business that provides goods or services to meet the needs of tourists and tourism organizers (Pratama \& Mandaasari, 2020; Regeg et al., 2019).

Potential can be developed following global market trends or sociological analysis of tourists and other trends. Considering that tourism is the backbone of a country's economy, the tourism industry has penetrated the creative economy sector. In the context of tourism development and creative economic development, Kemenparekraf/Baparekraf divides the development potential policy and the potential development of the tourism sector into four sub-chapters, namely:

a) Tourism destinations are the main core of tourism development. In its development, tourist attractions should be built synergistically by paying attention to tourism supporting facilities, public facilities, and accessibility/facilities and infrastructure. Tourism development must be community-based and adopt a complete and sustainable system.

b) The guideline for developing tourism potential and creative economy issued by the Ministry of Tourism and Creative Economy includes the potential for tourism marketing development that has been pioneered long ago. Potential is the main capital to encourage the acceleration of Indonesian tourism marketing.

c) Indonesia has compiled several potential provisions as a capital to accelerate the tourism industry.

d) Potential for Development of Tourism Institutions.

Tourism development is supported by related institutions effectively. In the context of national tourism development, Indonesia already has institutions in the tourism sector such as:

a) Strengthening of organizations both at local and national levels

b) Quality of tourism resources

c) Tourism as a multi-sectoral activity and the existence of supporting regulations 
d) The momentum of indonesia's demographic bonus (guide to the potential development of the tourism and creative economy sector kemenparekraf/baparekraf of the republic of indonesia/ accessed on 23 august 2021).

Tengku Amir Hamzah Stabat Park is synonymous with the poetry and works of Tengku Amir Hamzah. Art performances in the form of the musicalization of Tengku Amir Hamzah's poetry are often performed in parks and other art performances. An open stage with a book-shaped building on it contains the poem "Berdiri Aku" which is an implied meaning that the garden is synonymous with the poetry of Tengku Amir Hamzah. All levels of society in Langkat Regency who come from ethnic Malays and non-Malays are familiar with the works and activities of musical poetry by Tengku Amir Hamzah. Society in general has an artistic soul. However, this potential has not been developed by the Millennial Generation as a cultural tourism destination and attraction (Surbakti et al., 2019). Along with the times, the historical trend that is very prominent in the modern era is the change towards globalization, which is a process that produces a single world. There is homogenization and interdependence in the political, economic, and cultural fields. People's lives in the world are becoming interdependent and globalized. Humanity is understood as a real sociological unity and includes all people living on earth. According to Sztompka (2004), in globalization, people can talk about the global structure of political, economic, and cultural relations that develop beyond traditional boundaries and bind community units that were previously separated in a single system, namely the global system. The Langkat community has also not escaped the impact of globalization that has hit cultural life and left traditional values, traditions, customs, and Islamic life that have long been imprinted.

The Millennial Generation is a generation of people who were born in 1981 until the birth of the early 2000s, just when advanced technology such as gadgets has been widely used in society. They are generally familiar with gadgets from an early age, which is then marked by the generation of technology and information literacy. Narcissism is a term that is specifically addressed and as a marker for the Millennial Generation and this refers to the changes that occur in the individualistic or self-centered selfish generation. One of the negative sides of the Millennial Generation relates to problems in the realm of speech and language as a result of using gadgets with various applications for a long time every day. Lacan calls this phenomenon schizophrenia (Sarup, 2008).

Tanjung Pura and Stabat millennials generation are also experience this phenomenon. The Millennial Generation in the Tanjung Pura Azizi Mosque area, which is known to be very religious, did not escape the negative side effects of the massive use of technology. There is widespread cultural degradation that can threaten the nobility of the past cultural heritage. The negative side of the Indonesian millennial phenomenon can also be seen in the Stabat millennial generation who tend not to understand Tengku Amir Hamzah's poetry. There was an identity crisis. The phenomenon of identity turbulence due to the invasion of foreign values from all directions is a dilemma for postmodern society Ibrahim (2011), namely the generation that does not care about the social conditions around them.

Identity in the cultural studies perspective is understood as a marker of differences related to the lifestyle of "youth" which is generally the tendency of the Indonesian Millennial Generation (Barker, 2009). They are a representation of the phenomenon of consumerism with various activities that are fun without the responsibility. The young generation of Langkat did not escape from the global influence that also hit Indonesia, namely being uprooted from the cultural roots and strong teachings of Islam. The identity and traditional values of the Malay community are one of the cultural capitals that can be seen from the literary works of the North Sumatran Malay community and as the cultural treasures of the nation. These descriptions include (a) the ability to do good and benevolence according to Malay cultural norms, (b) loyalty to Malay cultural norms and rules, (c) courtesy and ethics according to Malay culture, (d) humble, (e) obedient and being obedient to parents and following customs and traditions, (f) being wise and wise, and (g) holding on to the mandate firmly (Takari et al, 2018). The identity and description of the Malay community above need to be known by the Langkat Millennial Generation as local wisdom as a moral guide, and this identity is commonly found in Malay poetry, gurindam, or songs which are usually full of values. In Malay culture, religion is the basis of culture and art is an expression of culture (Takari, 2018).

The characteristics and descriptions that contain the values of the Langkat Malay community above are the local ethical values of the Langkat Malay community. In tourism, the contribution and balance of values need to be observed and referred to as local ethical values. Moral ethical values are a set of people's beliefs that are constructed to direct the quality of their interactions with the environment, nature, humans, and their relationship with the Creator. Nine principles of environmental ethics are relevant to strengthening local ethics, namely (1) being respectful towards nature, (2) being responsible, (3) cosmic solidarity, (4) loving and caring for nature, (5) no harm (does not threaten the existence of other living things) (6,) (7) live simply and in harmony with nature, (8) democracy

Nasution, I., Surbakti, A., \& Sebayang, V. A. (2021). Development of art, culture, and literature attractions for millennial generations. International Journal of Linguistics, Literature and Culture, 7(6), 517-524. https://doi.org/10.21744/ijllc.v7n6.1982 
(diversity and plurality), and (9) have moral integrity. Local ethical values are sourced from customs, culture, and community structures that exist in tourism destinations. To encourage and improve ethical practices in tourism development in the context of global tourism, UNWTO established the Global Code of Ethics in Tourism (Teguh, 2015).

Local ethical values derived from the customs, culture, and structure of the Malay community in Stabat and Tanjung Pura above are the same as the cultural components of cultural tourism. Cultural tourism is an activity that allows tourists to know and gain new experiences about the different ways of life of other people, in reflecting on their customs, religious traditions, and intellectual ideas in an unfamiliar cultural heritage (Borley, 1996). The definition of cultural tourism above is the same as the new tourism phenomenon Teguh (2015), which explains the important role in tourism development through strengthening the unique values of certain regions and local wisdom believed by the community as a tourist attraction. Cultural tourism is closely related to high arts and community differentiation (Cole, 2006). Based on this limitation, the cultural heritage of the Langkat Malay community becomes important and needs to be developed as an attraction in Tengku Amir Hamzah Stabat Park. According to Lyotard in Sarup (2008), nowadays small narratives such as local wisdom have again got a place in social life, namely to regulate the socio-cultural life of the community as one of the resources for economic development.

\section{Conclusion}

Tengku Amir Hamzah Stabat Park has great potential in tourism development according to the concept of a new tourism phenomenon, namely cultural tourism. Tourism or everything related to tourism is a business that provides goods or services that function to meet the needs of tourists and tourism organizers. So that all industries or parties involved in its development must understand the new tourism phenomenon. Art workers have started to fill the park with various activities as well as young literary activists who like the works of Tengku Amir Hamzah. Although known as having a high culture, the Millennial Generation of Langkat Regency has also experienced the impact of globalization and technology so that the noble values of their cultural heritage have begun to disappear. Following the new tourism phenomenon, the embodiment of locality elements through strengthening the unique values of regional characteristics and local wisdom which is believed by the community to be used as tourist attractions must be encouraged as widely as possible in tourism development at the local level, such as in Taman Amir Hamzah Stabat. Cultural heritage values are the cultural capital of the Langkat Millennial Generation concerning the 4.0 Industrial Revolution, namely building the nation through cultural tourism. The development of artistic, cultural and literary attractions at Tengku Amir Hamzah Stabat Park is Indonesia's demographic momentum related to the Tourism and Creative Economy Development of the Ministry of Tourism and Creative Economy of the Republic of Indonesia.

\section{Conflict of interest statement}

The authors declared that they have no competing interest.

Statement of authorship

The authors have a responsibility for the conception and design of the study. The authors have approved the final article.

Acknowledgments

We are grateful to two anonymous reviewers for their valuable comments on the earlier version of this paper. 


\section{References}

Bachleitner, R., \& Zins, A. H. (1999). Cultural tourism in rural communities: The residents' perspective. Journal of business research, 44(3), 199-209. https://doi.org/10.1016/S0148-2963(97)00201-4

Barker, C. (2009). Cultural Studies Teori \& Praktik, terj. Nurhadi, Yogyakarta: Kreasi Wacana.

Borley, L. (1996). Heritage and Environment Management: The International Perspective. Dalam Nuryathi, W, 180188.

Boulanger, P. M., \& Bréchet, T. (2005). Models for policy-making in sustainable development: The state of the art and perspectives for research. Ecological economics, 55(3), 337-350. https://doi.org/10.1016/j.ecolecon.2005.07.033

Bungin, B. (2010). Penelitian Kualitatif: Komunikasi, Kebijakan Publik, dan Ilmu Sosial Lainnya.

Chitra, B. P. (2019). Puisi-Puisi Liris Karya Tengku Amir Hamzah dalam Perspektif Kajian Budaya.

Cole, S. (2006). 6. Cultural Tourism, Community Participation and Empowerment. In Cultural tourism in a changing world (pp. 89-103). Channel View Publications.

Cresswell, J. W. (2015). Penelitian kualitatif \& desain riset: memilih di antara lima pendekatan. Yogyakarta: Pustaka Pelajar.

Gallicano, T. D. (2013). Relationship management with the Millennial generation of public relations agency employees. Public Relations Review, 39(3), 222-225. https://doi.org/10.1016/j.pubrev.2013.03.001

Gunn, C. A., \& Var, T. (2020). Tourism planning: Basics, concepts, cases. Routledge.

Ibrahim, I. S. (2011). Kritik budaya komunikasi: budaya, media, dan gaya hidup dalam proses demokratisasi di Indonesia. Jalasutra.

Kemenristekdikti, (2018). Kebijakan Kemenristekdikti Menghadapi Globalisasi Pendidikan \& Revolusi Industri 4.0. Jakarta: Kemenristekdikti.

Kim, H., Cheng, C. K., \& O’Leary, J. T. (2007). Understanding participation patterns and trends in tourism cultural attractions. Tourism management, 28(5), 1366-1371. https://doi.org/10.1016/j.tourman.2006.09.023

Koe, W. L., Sa'ari, J. R., Majid, I. A., \& Ismail, K. (2012). Determinants of entrepreneurial intention among millennial generation. Procedia-Social and Behavioral Sciences, 40, 197-208. https://doi.org/10.1016/j.sbspro.2012.03.181

Lee, C. K., \& Han, S. Y. (2002). Estimating the use and preservation values of national parks' tourism resources using a contingent valuation method. Tourism management, 23(5), 531-540. https://doi.org/10.1016/S02615177(02)00010-9

Pratama, I. G. S., \& Mandaasari, I. A. C. S. (2020). The impact of tourism development on the economic, cultural and environmental aspects of local communities. International Research Journal of Management, IT and Social Sciences, 7(1), 31-36. https://doi.org/10.21744/irjmis.v7n1.819

Regeg, I. M., Triguna, I. B. G. Y., \& Winaja, I. W. (2019). Values of aesthetic and religiosity towards tourism attraction. International Research Journal of Management, IT and Social Sciences,6(2), 1-11. https://doi.org/10.21744/irjmis.v6n2.600

Richards, G. (2018). Cultural tourism: A review of recent research and trends. Journal of Hospitality and Tourism Management, 36, 12-21. https://doi.org/10.1016/j.jhtm.2018.03.005

Sarup, M. (2008). Panduan Pengantar Untuk Memahami Poststrukturalisme \& Posmodernisme. Yogyakarta: Jalasutra.

Setiadi, E. M., \& Kolip, U. (2011). Pengantar sosiologi: pemahaman fakta dan gejala permasalahaan sosial: teori, applikasi dan pemecahannya. Kencana.

Shoval, N., \& Raveh, A. (2004). Categorization of tourist attractions and the modeling of tourist cities: based on the co-plot method of multivariate analysis. Tourism Management, 25(6), 741-750. https://doi.org/10.1016/j.tourman.2003.09.005

Spillane, J. J. (1994). Pariwisata Indonesia: siasat ekonomi dan rekayasa kebudayaan (Vol. 5). Kanisius.

Squire, S. J. (1994). The cultural values of literary tourism. Annals of Tourism Research, 21(1), 103-120. https://doi.org/10.1016/0160-7383(94)90007-8

Surbakti, A., Arwina, S., dan Riko, A. R. P. (2019). Puisi-Puisi Liris Tengku Amir Hamzah Sebagai Pengembangan Destinasi Pariwisata Budaya di Tanjung Pura. Penelitian TALENTA USU/FIB-USU.

Sztompka, P. (2004). Sosiologi Perubahan Sosial, terjemahan Alimandan. Jakarta: Prenada Media.

Takari, M. (2018). Konsep Kebudayaan dalam Islam. Universitas Sumatera Utara: Fakultas Ilmu Budaya.

Teguh, F. (2015). Tata kelola destinasi membangun ekosistem pariwisata.

Nasution, I., Surbakti, A., \& Sebayang, V. A. (2021). Development of art, culture, and literature attractions for millennial generations. International Journal of Linguistics, Literature and Culture, 7(6), 517-524. https://doi.org/10.21744/ijllc.v7n6.1982 
Teguh, F. (2020). The Future of Tourism and Hospitality Business Model in The New Normal: Oppurtunity for Resilience and Sustainable Tourism. Disampaikan dalam Web Seminar Pariwisata Indonesia Pasca Covid-19 Peran Penting SDM yang Memahami Pariwisata Berkelanjutan. Jakarta: Universitas Pelita Harapan, 29 Mei 2020.

Wall, T., Liu, Y., Spero, C., Elliott, L., Khare, S., Rathnam, R., ... \& Yu, J. (2009). An overview on oxyfuel coal combustion-State of the art research and technology development. Chemical engineering research and design, 87(8), 1003-1016. https://doi.org/10.1016/j.cherd.2009.02.005

Yoeti, O. A. (2013). Komersialisasi seni budaya dalam pariwisata. 